\title{
GENETIC DIVERSITY IN AMBURANA (Amburana cearensis) ACCESSIONS: HIERARCHICAL AND OPTIMIZATION METHODS
}

Ana Valéria Vieira de Souza $2^{*} \odot$, Jackson Rafael de Sá Carvalho ${ }^{3} \odot$, Evelyn Sophia Silva Costa ${ }^{4}$, Cristina

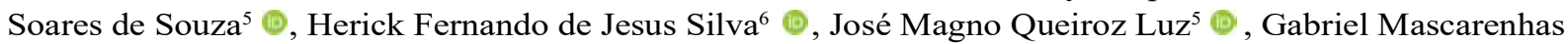

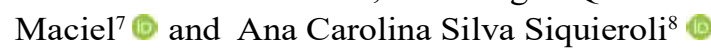

\footnotetext{
${ }^{1}$ Received on 07.07.2020 accepted for publication on 17.12.2020.

${ }^{2}$ Empresa Brasileira de Pesquisa Agropecuária, Petrolina, PE - Brasil. E-mail: <ana.souza@embrapa.br>.

${ }^{3}$ Universidade Estadual de Feira de Santana, Programa de Pós-Graduação em Recursos Genéticos Vegetais, Feira de Santana, BA - Brasil. E-mail: <rafael_carvalho@hotmail.com>.

${ }^{4}$ Universidade Estadual de Feira de Santana, Programa de Pós-Graduação em Biotecnologia, Feira de Santana, BA - Brasil. E-mail: <evelyn.sophia@hotmail.com>.

${ }^{5}$ Universidade Federal de Uberlândia, Instituto de Ciências Agrarias, Uberlândia, MG - Brasil. E-mail: <cristina.genetica@gmail.com> and <jmagno@ufu.br>.

${ }^{6}$ Universidade Federal de Uberlândia, Programa de Pós-Graduação em Agronomia, Uberlândia, MG - Brasil. E-mail: <herickfernando@ gmail.com>.

${ }^{7}$ Universidade Federal de Uberlândia, Instituto de Ciências Agrarias, Monte Carmelo, MG - Brasil. E-mail: <gabrielmaciel@ufu.br>.

${ }^{8}$ Universidade Federal de Uberlândia, Instituto de Biotecnologia, Uberlândia, MG - Brasil. E-mail: <carol@ufu.br>.

*Corresponding author.
}

\begin{abstract}
The evaluation of accessions in a germplasm bank is essential for determining the potential parents in conservation programs, especially for native trees. This study aimed to determine the genetic diversity among 68 Amburana cearensis genotypes from different locations in the state of Pernambuco, Brazil. Their genetic patterns were evaluated by Inter Simple Sequence Repeat (ISSR) molecular markers and genetic divergence was evaluated through multivariate analyses using different clustering methods. The optimization method used (Tocher) was in agreement with all the hierarchical models used, in which clustering of the genotypes occurred similarly, specifically for the accession BB116, which is an important genetic material to be preserved and studied. Among the various hierarchical methods applied, the Average Linkage method exhibited higher discrimination power, allowing identification of a larger number of divergent groups, thus implying wide genetic diversity among $A$. cearensis accessions.
\end{abstract}

Keywords: Caatinga; Genetic conservation; Native tree.

\section{DIVERSIDADE GENÉTICA ENTRE ACESSOS DE AMBURANA (Amburana cearensis): MÉTODOS HIERÁRQUICOS E DE OTIMIZAÇÃO}

\begin{abstract}
RESUMO - A avaliação de acessos em um banco de germoplasma é essencial para determinar os potenciais genitores em programas de conservação, especialmente para árvores nativas. O objetivo do trabalho foi verificar a diversidade genética entre 68 genótipos de Amburana cearensis situados em diferentes localidades no estado de Pernambuco, Brasil. Os padrões genéticos foram avaliados por marcadores moleculares Inter Simple Sequence Repeats (ISSR) e a divergência genética por meio de análises multivariadas empregando-se diferentes métodos de agrupamento. O método de otimização empregado (Tocher) foi concordante com todos os modelos hierárquicos utilizados, onde o agrupamento dos genótipos ocorreu de forma semelhante, especificamente para o acesso BB116, sendo este um importante material genético a ser preservado e estudado. Dentre os vários métodos hierárquicos aplicados, o de Ligação Média apresentou maior poder de discriminação, permitindo a identificação de maior quantidade de grupos divergentes, inferindo assim grande diversidade genética entre os acessos de A. cearensis.
\end{abstract}

Palavras-Chave: Caatinga; Conservação genética; Arvore nativa.

Silf (ce) EY

Revista Árvore 2021;45:e4508 http://dx.doi.org/10.1590/1806-908820210000008 


\section{INTRODUCTION}

Amburana cearensis (Allem.) A. C. Smith (Fabaceae) or amburana is a tree native to the Caatinga (Brazilian xeric shrubland and thorn forest) with multiple uses, such as lumber; medicinal uses, attributed to coumarin, the active ingredient present in bark and roots; ornamental use; reforestation in agroforestry systems (Pimentel and Guerra, 2015); and forage. It is also important for bee raising as it provides nectar in the dry season of the year (Silva et al., 2014). All these features establish $A$. cearensis as a species of great socioeconomic and environmental importance in the locations in which it develops. In Brazil, it is found at altitudes that range from $20-800$ $\mathrm{m}$ in regions where average annual rainfall values can range from 500 to $1700 \mathrm{~mm}$ and temperatures from 19 to $29{ }^{\circ} \mathrm{C}$ (Carvalho, 1994). It can reach up to $20 \mathrm{~m}$ in height and $50 \mathrm{~cm}$ in trunk diameter and is characterized by pink flowers and dark, flat seed pods. Its seeds are dark and winged (Lorenzi and Matos, 2008). It has sexual propagation and a considerable percentage of germination (Angelim et al., 2007).

Evaluation of genetic diversity is essential for breeding and conservation of species. Reduction in genetic diversity makes a species more susceptible to environmental changes, reducing its chances of survival over time (Spigler et al., 2017). Knowledge of genetic diversity of $A$. cearensis becomes crucial in identification of parentage for establishing a breeding and conservation programs, providing conditions for development of cultivars as well as discovery of more promising genotypes in medicinal and adaptive aspects. However, collecting this information is still in the initial stage, leading to the need for studies regarding $A$. cearensis.

Molecular markers are useful tools to determine the extent of genetic diversity of populations of plants (Borém and Caixeta, 2016). Molecular techniques such as Inter Simple Sequence Repeats (ISSR) that allow identification of wide intra- and inter-specific diversity are used in studies due to precise evaluation (Lorenzoni et al., 2014) and their other advantages, such as quick performance, cost-benefit ratio, and small amount of DNA template. In addition, they do not require previous knowledge of target sequences ( $\mathrm{Ng}$ and Tan, 2015; Grover and Sharma, 2016). Consequently, ISSR is an effective tool for a variety of purposes, including identification of germplasm and evaluation of genetic diversity (Coutinho et al., 2014; Kumar and Agrawal, 2017; Cid-Contreras et al., 2019; Al Salameen et al., 2020; Xiang et al., 2020).

The analyses performed from molecular markers include clustering methods. The purpose of these methods is to separate an original group of observations into various subgroups in order to obtain homogeneity within the subgroup and heterogeneity among the subgroups. Genotypes are clustered by a process that is repeated on various levels, and a dendrogram is established, without concern for the optimal number of groups. This is suitable for identifying divergent genotypes with the greatest probability of success in crosses (Cargnelutti Filho et al., 2008). In optimization methods, groups are established by refining a determined clustering criterion, differing from hierarchical methods by the fact of the groups formed being mutually exclusive. In addition, diverse methods based on different measures of dissimilarity can lead to distinct clustering patterns (Cruz et al., 2014).

Studies that deal with genetic diversity of $A$. cearensis involving different clustering methods are still quite limited. Therefore, the aims of this study were to characterize the genetic divergence among 68 A. cearensis accessions by means of molecular traits; determine if there is consistency between the Tocher clustering method and different hierarchical methods (Gower, Average Linkage, UPGMA, Ward, Complete Linkage, and WPGMA); and indicate promising hybrid combinations for obtaining potentially important populations for $A$. cearensis breeding and conservation programs.

\section{MATERIAL AND METHODS}

The study was conducted from March 2017 to February 2018. The germplasm used is part of the Genetic Resources Program of Embrapa and was obtained through the project Medicinal and Aromatic Plants of the Northeast region, coordinated by Embrapa Semiárido, based in Petrolina, PE. The propagative materials used came from six populations in the following locations, with their respective abbreviations: Jutaí (J), Rocinha (RO), Lajedo (LA), Barra Bonita (BB), Caiçara (CA), and Baixa do Juazeiro (BJ), all situated in the state of Pernambuco, Brazil (Figure 1). 


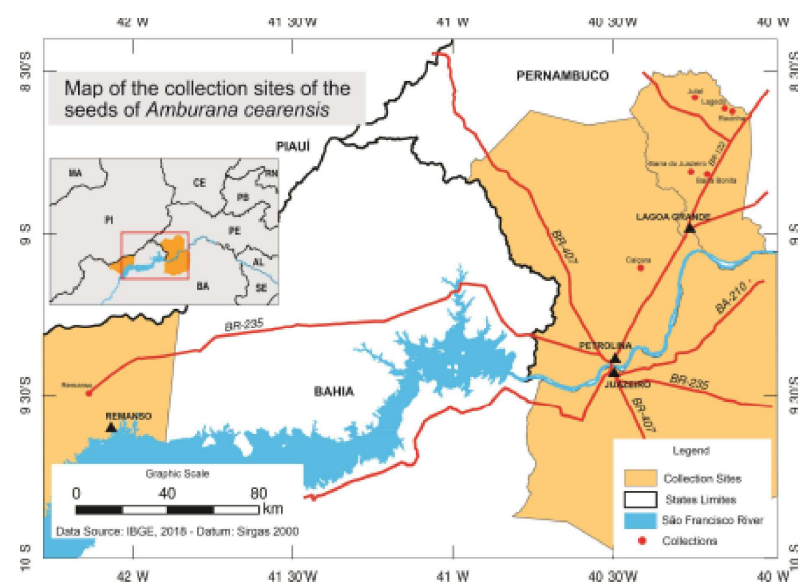

Figure 1 - Location of six collection points of Amburana cearensis accessions in the state of Pernambuco, Brazil.

Figura 1 - Localização dos seis pontos de coleta dos acessos de Amburana cearensis no estado de Pernambuco, Brasil.

Each accession was sown in seedling plugs containing a soil and sand mixture (1:1). Seven days after germination, the seedlings were transferred to $1000 \mathrm{~mL}$ capacity plastic bags containing the same substrate used in the previous step. Six months after transplanting, when the plants reached around 50 $\mathrm{cm}$ in height, molecular analyses began. Genomic DNA was obtained from young leaflets collected from plants kept in a greenhouse according to the method proposed by Nunes et al. (2011). Five ISSR primers recommended in the literature as polymorphic were used with the respective sequences $\left(5^{\prime}-3^{\prime}\right)$ and annealing temperatures (Ta): S-31AGAGAGAGAGAGAGAGVC $\left(49.6^{\circ} \mathrm{C}\right)$; UBC812GAGAGAGAGAGAGAGAAA $\left(51.6^{\circ} \mathrm{C}\right)$; UBC827ACACACACACACACACG $\left(50^{\circ} \mathrm{C}\right)$; UBC $890-\mathrm{VHV}$ GTGTGTGTGTGTGTT $\left(52^{\circ} \mathrm{C}\right)$; and UBC891-HVH TGTGTGTGTGTGTG $\left(52^{\circ} \mathrm{C} ; 51.6^{\circ} \mathrm{C}\right)$.

The ISSR amplification reactions were performed in a final volume of $25 \mu \mathrm{l}$, containing $50 \mathrm{ng}$ of DNA, $7.5 \mu \mathrm{l}$ of $5 \mathrm{X}$ reaction buffer, $1.5 \mathrm{mM}$ of $\mathrm{MgCl}_{2}, 200$ $\mu \mathrm{M}$ of each dNTP, $0.8 \mu \mathrm{M}$ of the primer (Sigma, USA), and 2.4 U of Taq DNA polymerase (Go Taq Flexi, Promega, USA). The reactions were conducted in a gradient thermal cycler (Multigene Gradient, Labnet International, USA) programmed for an initial denaturation step of $2 \mathrm{~min}$ at $95{ }^{\circ} \mathrm{C}$, followed by 40 cycles of denaturation at $95{ }^{\circ} \mathrm{C}$ for $45 \mathrm{sec}$. Annealing temperature was defining in accordance with each primer. Both annealing processes occurred for $1 \mathrm{~min}$ and extension of the primers was at $72{ }^{\circ} \mathrm{C}$ for $2 \mathrm{~min}$. A final extension step was carried out at $72^{\circ} \mathrm{C}$ for $5 \mathrm{~min}$.
The bands generated by amplification of the genomic DNA from each accession were used as data for interpretation in this study. The bands amplified by the same primer that occupied the same position on the gel were considered as belonging to the same gene loci. In accordance with the same principle, bands generated by the same primer but that occupy different positions were considered as belonging to different gene loci. Thus, the ISSR markers were genotyped regarding the presence (1) and the absence (0) of the bands, generating a binary matrix, used for division of the variance among their components within and among populations (hierarchical levels).

Analysis of variance was performed on the data by the $\mathrm{F}$ test $(\mathrm{P}=0.05)$ and the means were compared by the Scott-Knott test $(\mathrm{P}=0.05)$. After that, multivariate analyses were performed for the purpose of determining genetic dissimilarity among the genotypes, obtaining the dissimilarity matrix by hierarchical methods. Genetic divergence was represented by dendrograms obtained by six hierarchical methods: Gower, Average Linkage, UPGMA, Ward, Complete Linkage, and WPGMA, and by the Tocher optimization method. The clustering by hierarchical methods was validated through the cophenetic correlation coefficient (CCC), calculated by the test of Mantel (1967). All the data obtained were analyzed using Genes v. 2015.5.0 software (Cruz, 2013).

\section{RESULTS}

The means test of the molecular pattern of the $A$. cearensis populations showed wide genetic diversity within the sampled populations themselves that exhibited distinct individuals in regard to DNA content (Table 1).

The cophenetic correlation coefficients for the different hierarchical methodologies (Gower: 0.84, Average Linkage: 0.48, UPGMA: 0.89, Ward: 0.43, Complete Linkage: 0.74, and WPGMA: 0.80) exhibited a suitable relationship between the distance matrix and the dendrogram generated, which shows fidelity in presentation of the dataset (Figure 2).

Thus, the genotypes were clustered in three to six distinct groups, when a cut was made considering $10 \%$ of dissimilarity. In all the hierarchical methods, Group I was represented only by the accession BB116, and for the other groups, genotype distribution was variable (Table 2).

Revista Árvore 2021;45:e4508 
Table 1 - Means testing of DNA content of 68 Amburana cearensis genotypes.

Tabela 1 - Teste de médias do conteúdo de DNA de 68 acessos de Amburana cearensis.

\begin{tabular}{|c|c|c|c|c|c|}
\hline Genotype & Mean & Genotype & Mean & Genotype & Mean \\
\hline$\overline{\mathrm{BB} 116}$ & $37.04 \mathrm{a}$ & J44 & $29.05 \mathrm{f}$ & BB 119 & $27.84 \mathrm{~h}$ \\
\hline $\mathrm{J} 45$ & $31.95 \mathrm{~b}$ & BJ88 & $28.98 \mathrm{~g}$ & LA110 & $27.80 \mathrm{~h}$ \\
\hline $\mathrm{J} 27$ & $31.33 \mathrm{c}$ & J55 & $28.89 \mathrm{~g}$ & BB117 & $27.76 \mathrm{~h}$ \\
\hline CA65 & $31.21 \mathrm{c}$ & RO93 & $28.87 \mathrm{~g}$ & $\mathrm{~J} 50$ & $27.70 \mathrm{~h}$ \\
\hline J19 & $30.99 \mathrm{~d}$ & $\mathrm{~J} 30$ & $28.73 \mathrm{~g}$ & $\mathrm{~J} 32$ & $27.65 \mathrm{~h}$ \\
\hline $\mathrm{J} 26$ & $30.87 \mathrm{~d}$ & RO95 & $28.71 \mathrm{~g}$ & BJ76 & $27.63 \mathrm{~h}$ \\
\hline CA135 & $30.61 \mathrm{~d}$ & J51 & $28.59 \mathrm{~g}$ & RO101 & $27.34 \mathrm{i}$ \\
\hline CA129 & $30.56 \mathrm{~d}$ & J49 & $28.53 \mathrm{~g}$ & $\mathrm{~J} 46$ & $27.30 \mathrm{i}$ \\
\hline $\mathrm{J} 35$ & $30.51 \mathrm{~d}$ & RO100 & $28.50 \mathrm{~g}$ & BB122 & $27.25 \mathrm{i}$ \\
\hline RO98 & $30.43 \mathrm{~d}$ & $\mathrm{~J} 43$ & $28.47 \mathrm{~g}$ & BB 120 & $27.06 \mathrm{i}$ \\
\hline J57 & $30.42 \mathrm{~d}$ & $\mathrm{~J} 40$ & $28.47 \mathrm{~g}$ & BB121 & $27.06 \mathrm{i}$ \\
\hline $\mathrm{J} 42$ & 30.04 e & RO97 & $28.40 \mathrm{~g}$ & CA66 & $26.95 \mathrm{i}$ \\
\hline BJ80 & $29.92 \mathrm{e}$ & RO109 & $28.38 \mathrm{~g}$ & BJ69 & $26.87 \mathrm{i}$ \\
\hline RO94 & $29.86 \mathrm{e}$ & RO90 & $28.32 \mathrm{~g}$ & BB124 & $26.71 \mathrm{i}$ \\
\hline RO99 & $29.82 \mathrm{e}$ & J41 & $28.31 \mathrm{~g}$ & $\mathrm{~J} 20$ & $26.38 \mathrm{j}$ \\
\hline $\mathrm{J} 53$ & $29.72 \mathrm{e}$ & RO104 & $28.20 \mathrm{~h}$ & BB127 & $26.30 \mathrm{j}$ \\
\hline $\mathrm{J} 25$ & $29.60 \mathrm{e}$ & $\mathrm{J} 36$ & $28.16 \mathrm{~h}$ & BJ81 & $26.19 \mathrm{j}$ \\
\hline J56 & $29.49 \mathrm{e}$ & LA111 & $28.16 \mathrm{~h}$ & BJ71 & $26.04 \mathrm{j}$ \\
\hline BB 125 & $29.32 \mathrm{f}$ & $\mathrm{J} 33$ & $28.13 \mathrm{~h}$ & BB126 & $26.00 \mathrm{j}$ \\
\hline J54 & $29.28 \mathrm{f}$ & BB115 & $27.96 \mathrm{~h}$ & $\mathrm{~J} 48$ & $25.37 \mathrm{k}$ \\
\hline RO89 & $29.19 \mathrm{f}$ & $\mathrm{J} 47$ & $27.92 \mathrm{~h}$ & RO107 & $25.35 \mathrm{k}$ \\
\hline RO105 & $29.16 \mathrm{f}$ & J17 & $27.92 \mathrm{~h}$ & & \\
\hline $\mathrm{J} 52$ & $29.08 \mathrm{f}$ & J34 & $27.89 \mathrm{~h}$ & & \\
\hline
\end{tabular}

Means followed by different letters differ from each other by the Scott-Knott test at the level of $5 \%$ significance.

Médias seguidas por letras distintas diferem entre si pelo teste de Skott Knott ao nivel de $5 \%$ de significância.

The Average Linkage method provided the best representation of the dendrogram, since it allowed better formation of subgroups, i.e., this method was able to distinguish the accessions in a more detailed way, classifying them with higher diversity, which is a relevant result for breeding purposes. In contrast, the UPGMA method generated the least satisfactory representation in cluster formation, detecting less genetic diversity among the accessions and, thus, dendrograms that are less useful depending on the desired purpose.

Cluster analysis by the Tocher method among the 68 accessions led to the formation of two groups, such that within each group, the matrices were considered to be genetically similar, and between groups, dissimilar (Table 3). Approximately $98.5 \%$ of the genotypes were concentrated in Group I, and the genotype BB116 alone composed Group II.

\section{DISCUSSION}

The genetic diversity within the A. cearensis populations can provide an estimate of apparent gene flow. Tree species generally have a mixed mating system, as well as long-distance pollen and seed dispersal, which favors the occurrence of gene flow among populations, thus increasing the genetic diversity within populations and decreasing the genetic differentiation among them (Zanettini and Cavalli, 2003). Species with pollination agents that reach great distances (such as wind, birds, or bats) and/or dispersers that distribute seeds across extensive areas (such as wind or large animals) have highest gene flow and consequently high genetic diversity within populations (Mori, 2003). Amburana cearensis is pollinated by insects (bees, flies, and moths) and seeds are wind dispersed (Araujo and Dantas, 2018). This information contributes to an understanding of this great genetic diversity among accessions.

The determination of groups of parents for hybridization can be determined based on genetic divergence among individuals (Martins et al., 2002). The most divergent individuals are the most suitable for performing crosses since they may produce a greater heterotic effect and genetic diversity in the segregating generations. This information is highly worthwhile for the species in question, which is still in a wild state in terms of domestication, and this type

Revista Árvore 2021;45:e4508 

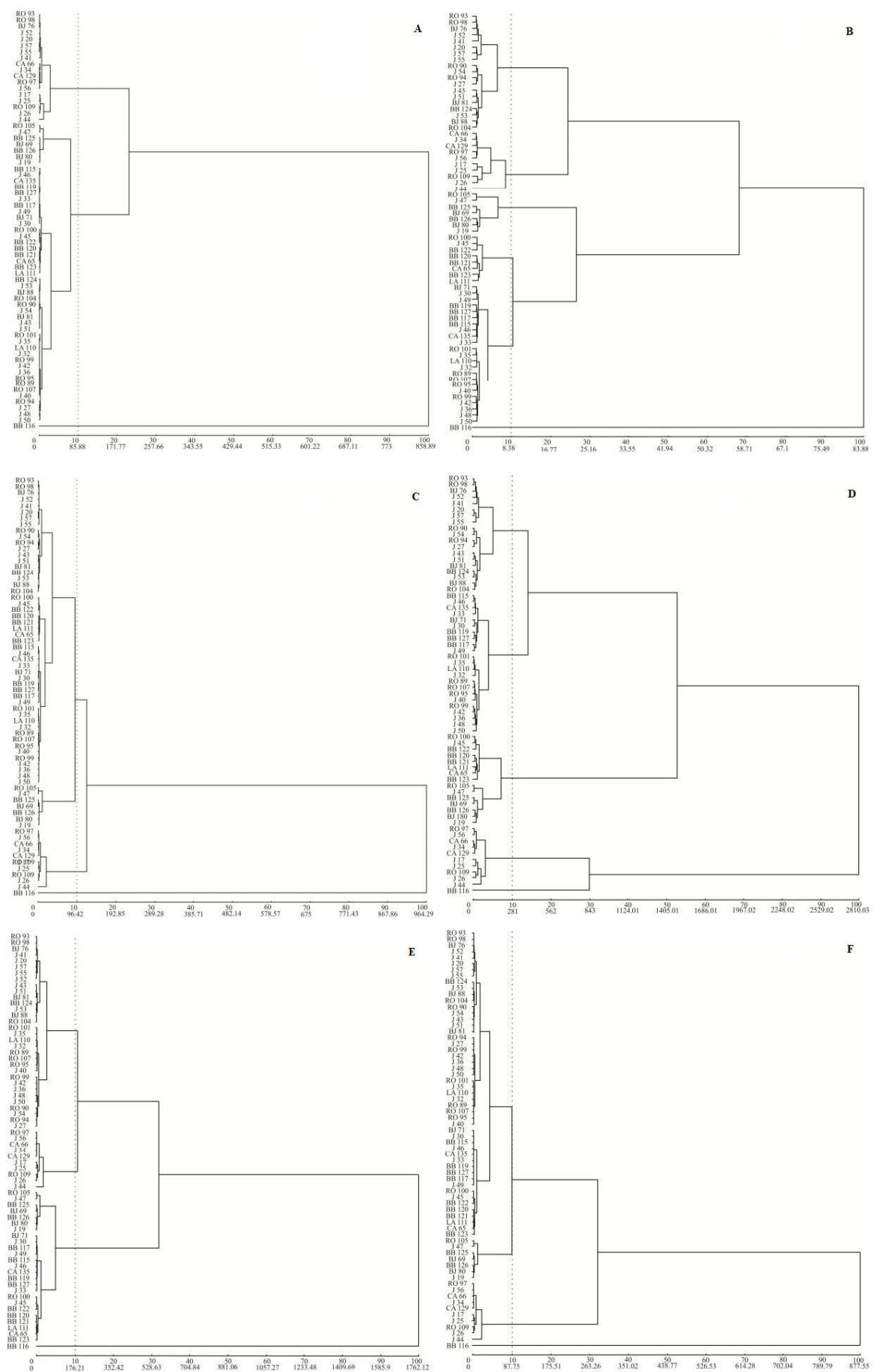

Figure 2 - Dendrograms representative of genetic dissimilarity among 68 Amburana cearensis genotypes using the following clustering methods: Gower (A), Average Linkage (B), UPGMA (C), Ward (D), Complete Linkage (E), and WPGMA (F) from the Euclidean distances obtained in different locations in the state of Pernambuco, Brazil.

Figura 2 - Dendrogramas representativos da dissimilaridade genética entre 68 acessos de Amburana cearensis utilizando os métodos de agrupamento: Gower (A), Ligação média (B), UPGMA (C), Ward (D), Vizinho mais distante (E) e WPGMA (F) a partir das distâncias euclidianas obtidas, em diferentes locais no estado de Pernambuco, Brasil. 
Table 2 - Division of Amburana cearensis genotypes in different genetic groups based on six hierarchical clustering methods.

Tabela 2 - Divisão de genótipos de Amburana cearensis em diferentes grupos genéticos baseada em seis métodos hierárquicos de agrupamento.

\begin{tabular}{|c|c|c|}
\hline $\begin{array}{l}\text { Hierarchical } \\
\text { method }\end{array}$ & Group & Genotypes \\
\hline \multirow{4}{*}{ Gower } & $\mathrm{I}$ & BB116 \\
\hline & II & $\begin{array}{l}\text { BB115, J46, CA135, BB119, BB127, J33, BB117, J49, BJ71, J30, RO100, J45, BB122, } \\
\text { BB120, BB121, CA65, BB123, LA111, BB124, J53, BJ88, RO104, RO90, J54, BJ81, J43, } \\
\text { J51, RO101, J35, LA110, J32, RO99, J42, J36, RO95, RO89, RO107, J40, RO94, J27, J48, } \\
\text { J50 }\end{array}$ \\
\hline & III & RO $\quad 105$, J47, BB125, BJ69, BB126, BJ80, J19 \\
\hline & IV & $\begin{array}{l}\text { RO93, RO98, BJ77, J52, J20, J57, J55, J41, CA66, J34, CA129, RO97, J56, J17, J25, } \\
\text { RO109, J26, J44 }\end{array}$ \\
\hline \multirow{6}{*}{ Average Linkage } & I & BB116 \\
\hline & II & $\begin{array}{l}\text { BJ71, J30, J49, BB119, BB127, BB117, BB115, J46, CA135, J33, } \\
\text { RO101, J35, LA110, J32, RO89, RO107, RO95, J40, RO99, J42, J36, J48, J50 }\end{array}$ \\
\hline & III & RO100, J45, BB122, BB120, BB121, CA65, BB123, LA111 \\
\hline & IV & RO105, J47, BB125, BJ69, BB126, BJ80, J19 \\
\hline & $\mathrm{V}$ & CA66, J34, CA129, RO97, J56, J17, J25, RO109, J26, J44 \\
\hline & VI & $\begin{array}{l}\text { RO93, RO98, BJ76, J52, J41, J20, J57, J55, RO90, J54, RO94, J27, J43, J51, BJ81, BB124, } \\
\text { J53, BJ88, RO104 }\end{array}$ \\
\hline \multirow[b]{3}{*}{ UPGMA } & $\overline{\mathrm{I}}$ & BB116 \\
\hline & II & RO97, J56, CA66, J34, CA129, J17, J25, RO109, J26, J44 \\
\hline & III & $\begin{array}{l}\text { RO93, RO98, BJ76, J52, J41, J20, J57, J55, RO90, J54, RO94, J27, J43, J51, BJ81, BB124, } \\
\text { J53, BJ88, RO104, RO100, J45, BB122, BB120, BB121, LA111, CA65, BB123, BB115, } \\
\text { J46, CA135, J33, BJ71, J30, BB119, BB127, BB117, J49, RO49, RO101, J36, LA110, J32, } \\
\text { RO89, RO107, RO95, J40, RO99, J42, J36, J48, J50, RO105, J47, BB125, BJ69, BB126, } \\
\text { BJ80, J19 }\end{array}$ \\
\hline \multirow{5}{*}{ Ward } & $\overline{\mathrm{I}}$ & BB116 \\
\hline & II & RO97, J56, CA66, J34, CA129, J17, J25, RO109, J26, J44 \\
\hline & III & $\begin{array}{l}\text { RO100, J45, BB122, BB120, BB121, LA111, CA65, BB123, RO105, J47, BB125, BJ69, } \\
\text { BB126, BJ80, J19 }\end{array}$ \\
\hline & IV & $\begin{array}{l}\text { BB115, J46, CA135, J33, BJ171, J30, BB119, BB127, BB117, J49, RO101, J35, LA110, } \\
\text { J32, RO89, RO107, RO95, J40, RO99, J42, J36, J48, J50 }\end{array}$ \\
\hline & $\mathrm{V}$ & $\begin{array}{l}\text { RO93, RO98, BJ76, J52, J41, J20, J57, J55, RO90, J54, RO94, J27, J43, J51, BJ81, BB124, } \\
\text { J53, BJ88, RO104 }\end{array}$ \\
\hline \multirow{4}{*}{ Complete Linkage } & $\bar{I}$ & BB116 \\
\hline & II & $\begin{array}{l}\text { RO105, J47, BB125, BJ69, BB126, BJ80, J19, BJ71, J30, BB117, J49, BB15, J46, CA135, } \\
\text { BB119. BB127 J33, RO100, J45, BB122, BB120, BB121. LA111 CA65. BB123 }\end{array}$ \\
\hline & III & RO97, J56, CA66, J34, CA129, J17, J26, RO109, J26, J44 \\
\hline & IV & $\begin{array}{l}\text { RO93, RO98, BJ76, J41, J20, J57, J55, J52, J43, J51, BJ81, BB124, J53, BJ88, RO104, } \\
\text { RO101, J35, LA110, J32, RO89, RO107, RO95, J40, RO99, J42, J36, J48, J50, RO90, J54, } \\
\text { RO94, J27 }\end{array}$ \\
\hline \multirow{4}{*}{ WPGMA } & $\overline{\mathrm{I}}$ & BB116 \\
\hline & II & RO97, J56, CA66, J34, CA129, J17, J25, RO109, J26, J44 \\
\hline & III & RO105, J47, BB125, BJ69, BB126, BJ80, J19 \\
\hline & IV & $\begin{array}{l}\text { RO93, RO98, BJ76, J52, J41, J20, J57, J55, BB124, J53, BJ88, RO104, RO90, J54, J43, } \\
\text { J51, BJ81, RO94, J27, RO99, J42, J36, J48, J50, RO101, J35, LA110, J32, RO89, RO107, } \\
\text { RO95, J40, BJ71, J30, BB115, J46, CA135, J33, BB119, BB127, BB117, J49, RO100, J45, }\end{array}$ \\
\hline
\end{tabular}

of directing serves as an essential tool for effective search by this process.

In analyzing the aspect of plant selection for seed collection, genetic diversity is fundamental for ensuring genetic gains by selection in plant breeding (Voss-Fels et al., 2019). In this case, the analyzed populations indicated potential for this purpose, since intrapopulational genetic diversity was satisfactory, conferred by diversity of groups shown in the six clustering methods applied. Similar results with application of similar methodologies were also reported in populations of Spondias lutea (Gois et al., 2014a) and Dimorphandra mollis (Oliveira et al., 2008).

\section{Revista Árvore 2021;45:e4508}


Table 3 - Representation of the clustering of 68 Amburana cearensis genotypes by the Tocher optimization method from Euclidean distances based on analysis of molecular markers.

Tabela 3 - Representação do agrupamento de 68 acessos de Amburana cearensis pelo método de otimização de Tocher a partir das distâncias euclidianas baseadas na análise de marcadores moleculares.

\begin{tabular}{cl}
\multicolumn{1}{c}{ Group } & \multicolumn{1}{c}{ Genotypes } \\
\hline I & RO93, RO98, BJ76, J52, J41, J20, J57, J55, BB124, J53, BJ88, RO104, J51, J43, BJ81, J54, RO90, J27, RO94, \\
& J50, J48, RO99, J42, J36, RO95, RO107, RO89, J40, RO101, J35, LA110, J32, BB115, J46, CA135, J33, \\
& BB119, BB127, BB117, J49, J30, BJ71, RO100, J45, BB122, BB120, BB121, CA65, LA111, BB123, J56, \\
II & RO97, J34, CA66, CA129, J19, BB126, BJ80, J25, J17, BJ69, BB125, RO109, J26, J47, RO105, J44 \\
\hline Total & BB116 \\
\hline
\end{tabular}

According to McKay et al. (2005), the genetic diversity within populations is important because the collection of material from different forest environments that have edaphic and climatic characteristics similar to that to be restored have a direct effect on efforts for restoration and conservation of native species. Exotic genotypes can reduce the success of these types of efforts through poor adaptation to local conditions or through reduction on the gene flow of adjacent native populations.

The genotype BB116 representing an important accession that merits more attention since it has the genetic identity with higher divergence from the other individual's analysis by the Tocher method. This response may indicate that this accession has a different origin from the others. A similar result was found in Phaseolus vulgaris (Cargnelutti Filho et al., 2008), in which application of this optimization method separated the groups in a manner quite similar to that obtained in this study. Likewise, in a study with individuals of $S$. lutea, $80 \%$ of the accessions were clustered in one group alone by Jaccard genetic similarity (Gois et al., 2014a).

Therefore, as the accession BB116 has these characteristics, it has considerable potential for use in crosses for generating hybrids. At the other extreme, information regarding the most similar pairs is useful in programs involving backcrosses, in which the use of similar parents (basically differentiated by the allele to be transferred) allows the recurrent parent to be recovered (Araujo et al., 2002). This information is highly relevant for conservation programs since it assists actions that allow domestication of $A$. cearensis with wide genetic diversity, together with selection of good adaptive and agronomic traits.

Application of the Gower, Average Linkage, UPGMA, Ward, Complete Linkage, and WPGMA hierarchical methods and of the Tocher optimization method indicated the existence of genetic variability among the genotypes. The number of groups formed by the Average Linkage method was higher (six groups) than that obtained by the other hierarchical methods, showing greater discriminating power. This allows identification of more groups containing similar accessions.

The results generated in this study confirm the importance of molecular markers for the proposed objective, and this study is in agreement with other studies reported in the literature (Jiang et al., 2019; Al Salameen et al., 2020; Xiang et al., 2020; ZacaríasCorrea et al., 2020). The results also reinforce the importance of application of this technique in studies of other native tree species that still lack greater investigation in the scientific community and are exposed to extinction.

\section{CONCLUSIONS}

There is genetic diversity among the $A$. cearensis accessions, confirmed by detection of different groups formed by the clustering methods, suggesting that studies directed to crosses be performed among accessions of these different groups. The Average Linkage hierarchical method exhibited greater discrimination power, allowing identification of a larger number of groups containing similar accessions. The Tocher optimization method proved to be effective in representing the genetic distance of the accessions in this study, since it was in agreement with all the hierarchical methods, revealing that the accession $\mathrm{BB} 116$ is the most divergent of the accessions and is therefore, indicate for performing crosses and for use in conservation programs of native tree species.

\section{AUTHOR CONTRIBUTIONS}

Conceived and designed the analysis: AVVS, JRSC, ESSC. Material preparation, data collection and

Revista Árvore 2021;45:e4508 
analysis: AVVS, JRSC, ESSC, CSS, HFJS. Wrote the paper: AVVS, HFJS, JMQL, GMM, ACSS. Revision and edition of the manuscript: AVVS, JMQL, GMM, ACSS. Research supervision: AVVS, JMQL. All authors read and approved the final manuscript.

\section{ACKNOWLEDGEMENTS}

To Coordenação de Aperfeiçoamento de Pessoal de Nível Superior (CAPES), Conselho Nacional de Desenvolvimento Científico e Tecnológico (CNPq), and Fundação de Amparo à Pesquisa do Estado de Minas Gerais (Fapemig) for financially supporting.

\section{REFERENCES}

Al Salameen F, Habibi N, Al Amad S, Kumar V, Dashti J, Talebi L, et al. Genetic diversity analysis of Rhanterium eppaposum Oliv. by ISSRs reveals a weak population structure. Current Plant Biology. 2020;21:1001382. doi:10.1016/j.cpb.2020.100138

Angelim AES, Moraes JPS, Silva, JAB, Gervásio RCRG. Germinação e aspectos morfológicos de plantas de Umburana de Cheiro (Amburana cearensis) encontradas na região do Vale do São Francisco. Nota científica. Revista Brasileira de Biociências, 2007;5(2):1062-1064.

Araujo DG, Carvalho SP, Alves RM. Divergência genética entre clones de cupuaçuzeiro (Theobroma grandiflorum Willd ex Spreng Schum). Ciência e Agrotecnologia. 2002;26(1):13-21.

Araujo MD, Dantas BF. Umburana-de-cheiro Amburana cearensis (Allemão) A.C.Sm. Nota Técnica 09. Londrina: ABRATES; 2018.

Borém A, Caixeta E. Marcadores moleculares. Viçosa: Editora UFV; 2016. ISBN 9788572695558

Cargnelutti Filho A, Ribeiro ND, Reis RCP dos, Souza JR, Jost E. Comparação de métodos de agrupamento para o estudo da divergência genética em cultivares de feijão. Ciência Rural. 2008; 38(8):2138-2145. doi:10.1590/S010384782008000800008 .

Carvalho PER. Espécies Florestais Brasileiras: Recomendações Silviculturais, Potencialidades e Uso da Madeira. Brasília: EMBRAPA; 1994. ISBN 8585007338
Cid-Contreras RC, Mascorro-Gallardo JO, Valadez-Moctezuma E. Genotyping and molecular analysis of transgenic sequences in chrysanthemum (Chrysanthemum X morifolium Ramat). Crop Breeding and Applied Biotechnology, 2019;19(3):285-290. doi:10.1590/198470332019v19n3a40.

Coutinho JP, Carvalho A, Lima-Brito J. Genetic diversity assessment and estimation of phylogenetic relationships among 26 Fagaceae species using ISSRs. Biochemical Systematics and Ecology, 2014;54(4): 247-256. doi:10.1016/j.bse.2014.02.012

Cruz CD. Genes: A software package for analysis in experimental statistics and quantitative genetics. Acta Scientiarum. Agronomy, 2013;35(3):271-276. doi:10.4025/actasciagron.v35i3.21251

Cruz CD, Carneiro PCS, Regazzi AJ. Modelos biométricos aplicados ao melhoramento genético. Viçosa: Editora UFV; 2014. ISBN 8572691510

Gois IB, Ferreira RA, Silva-Mann R, Blank MFA, Santos Neto EM. Diversidade genética entre indivíduos de Spondias lutea L. procedentes do Baixo São Francisco Sergipano, por meio de marcadores RAPD. Revista Árvore. 2014a;38(2):261-270. doi:10.1590/S010067622014000200006

Grover A, Sharma PC. Development and use of molecular markers: past and present. Critical Reviews in Biotechnology. 2016;36(2):290-302. doi: 10.3109/07388551.2014.959891

Jiang H, Long W, Zhang H, Mi C, Zhou T, Chen $\mathrm{Z}$. Genetic diversity and genetic structure of Decalobanthus boisianus in Hainan Island, China. Ecology and evolution. 2019; 9(9):5362-5371. doi:10.1002/ece 3.5127

Kumar J, Agrawal V. Analysis of genetic diversity and population genetic structure in Simarouba glauca, DC. (an important bio-energy crop) employing ISSR and SRAP markers. Industrial Crops and Products. 2017;100:198-207. doi:10.1016/j.indcrop.2017.02.035

Lorenzi H, Matos FJA. Plantas Medicinais no Brasil: nativas e exóticas. Nova Odessa, SP: Instituto Plantarum; 2008.

Lorenzoni RM, Soares TCB, Santiago VF, 
Silva JA, Coelho RI. Utilização de marcadores ISSR na avaliação da divergência genética entre acessos de biribazeiro. Revista Brasileira de Fruticultura. 2014;36:251-257. doi:10.1590/S010029452014000500029

Mantel N. The detection of disease clustering and a generalized regression approach. Cancer Research, 1967;27(2):209-220.

Martins IS, Pires IE, Oliveira MCD. Divergência genética em progênies de uma população de Eucalyptus camaldulensis Dehn. Floresta e Ambiente. 2002;9:81-89.

Mckay JK, Christian CE, Harrison S, Rice KJ. "How local is local"? A review of practical and conceptual issues in the genetics of restoration. Restoration Ecology. 2005;13:432-440. doi:10.1111/j.1526100X.2005.00058.x

Mori ES. Genética de Populações Arbóreas: orientações básicas para seleção e marcação de matrizes. São Paulo: IF Série Registros; 2003.

$\mathrm{Ng}$ WL, Tan SG. Inter-simple sequence repeat (ISSR) markers: are we doing it right. ASM Science Journal. 2015;9(1):30-39.

Nunes CF, Ferreira JL, Fernandes MCN, Breves SS, Generoso AL, Soares BDF, et al. An improved method for genomic DNA extraction from strawberry leaves. Ciência Rural. 2011;41(8):1383-1389.

Oliveira DA, Paula MFB, Pimenta MAS, Braga RF, Ferreira MFM, Rodrigues LA. Variabilidade genética de populações de fava d"anta (Dimorphandra mollis) da região Norte de Minas Gerais. Revista Árvore. 2008;32(2):3355-363. doi:10.1590/S010067622008000200018

Pimentel JVF, Guerra HOC. Crescimento inicial de Amburana Cearensis (Allem.) A. C. Smith em sistema agroflorestal no semiárido brasileiro. Ciência Florestal. 2015;25(3):771-780. doi:10.5902/1980509819681

Rodrigues HCA, Carvalho SP, Carvalho AA, Carvalho Filho JLS, Custódio TN. Avaliação da diversidade genética entre acessos de mamoneira (Ricinus communis L.) por meio de caracteres morfoagronômicos. Revista Ceres. 2010;57(6):773777. doi:10.1590/S0034-737X2010000600012

Santos MAC, Queiroz MA, Santos AS, Santos LC, Carneiro PCS. Diversidade genética entre os acessos de araçá de diferentes municípios do Semiárido baiano. Revista Caatinga. 2014;27(2):48-57.

Silva CAL, Damião DP, Pinto MSC, Silva KB, Targino LC. Survey of honey flora in the municipalities microregion of the Catolé do Rocha-PB. Revista Verde de Agroecologia e Desenvolvimento Sustentável. 2014;9(3):223-235.

Spigler RB, Theodorou K, Chang SM. Inbreeding depression and drift load in small populations at demographic disequilibrium. Evolution. 2017;71(1):81-94. doi:10.1111/evo.13103

Vieira EA, Carvalho FIF, Oliveira AC, Martins LF, Benin G, Silva JAG, et al. Associação da distância genética em trigo estimada a partir de caracteres morfológicos, caracteres fenológicos e dos componentes do rendimento de grãos. Revista Brasileira Agrociência. 2007;13(2):161-168.

Voss-Fels KP, Cooper M, Hayes BJ. Accelerating crop genetic gains with genomic selection. Theor Appl Genet 2019;132:669-686. doi.org/10.1007/ s00122-018-3270-8

Xiang L, Li XL, Wang XS, Yang J, Lv K, Xiong $Z Q$, et al. Genetic diversity and population structure of Distylium chinense revealed by ISSR and SRAP analysis in the Three Gorges Reservoir Region of the Yangtze River, China. Global Ecology and Conservation. 2020;21:e008052. doi:10.1016/j. gecco.2019.e00805

Zacarías-Correa AG, Lira-Noriega A, Pérez-Calix E, Samain MS, Wolfeet AD. Back to the future of a rare plant species of the Chihuahuan desert: tracing distribution patterns across time and genetic diversity as a basis for conservation actions. Biodiversity and Conservation. 2020;29:1821-1840. doi:10.1007/ s10531-020-01962-2

Zanettini MHB, Cavalli SS. Variabilidade genética em função do modo de reprodução. In: Freitas LB, Bered F, editors. Genética e evolução vegetal. Porto Alegre: Editora UFRGS; 2003. p.177-187. 